\title{
TOOLS FOR PERSONALIZED LEARNING-BASED TEACHER EDUCATION
}

\author{
Ausra Rutkiene \\ Vytautas Magnus University, Lithuania \\ Lina Kaminskiene \\ Vytautas Magnus University, Lithuania \\ Stefanija Alisauskiene \\ Vytautas Magnus University, Lithuania \\ Lina Milteniene \\ Vytautas Magnus University, Lithuania
}

Ausra Kazlauskiene

Siauliai University, Lithuania

Asta Siriakoviene

Siauliai University, Lithuania

Hafdís Guðjónsdóttir

University of Iceland, Iceland

\section{Jónína Vala Kristinsdóttir \\ University of Iceland, Iceland}

\section{Anna Katarzyna Woźniczka \\ University of Iceland, Iceland}

\begin{abstract}
Changes in the education from a teacher-centered to a student-centered approach requires changes in schools and in teacher education. One of possible ways is personalized learning (PL). It is a new concept in many countries around the world. PL is closely related to individualized, differentiated learning, inclusive education principles (Abbot, 2014; EDUCAUSE, 2013). PL builds on an understanding of learner: individual development, seeking of personal goals, taking into consideration individual differences and inclusion. $P L$ "challenges teachers to search for pedagogy and practices that will help them addressing diversity in their classroom" (Guðjónsdóttir, 2000, p.9). Different methods and tools (e-tools as well) might be used for PL such as digital storytelling, three step interview, e-portfolio. Paper presents theoretical analysis of links between aspects of effective learning (good knowledge of each student; shared teacher and student responsibility within the learning process; personal learner involvement, linking to individual motivation, experience, and aspirations; collaboration, participation and involvement in the learning process; effective use of information technology and other learning resources (Williams, 2013)) and methods/tools for PL.
\end{abstract}


Keywords: digital storytelling, e-portfolio, personalized learning, teacher education, three step interview.

\section{Introduction}

Personalized learning (PL) is highly related to student-centered pedagogical approaches, inclusion and meeting of personal needs of each student. "Personalized Learning in teacher education is concerned with how modes of teaching influence student-teacher learning and, in turn, how the ways in which student teachers learn may influence their future teaching” (UNESCO, 2020, p. 17). "PL is therefore a progressive learner-driven model, through which student teachers engage actively, deeply and reflectively in rigorous challenges and meaningful authentic tasks to demonstrate desired outcomes" (Zmuda, Curtis and Ullman, 2015, form (UNESCO, 2020, p. 17). The concept of PL "embraces four core elements:

a) Collaborative dialogue, co-construction, personal reflection and mutual ownership by learners and teachers;

b) Flexible content, tools, and learning environments to facilitate learners' interests and needs and teacher-learner collaboration;

c) Targeted support in response to learner interests and needs, through learning

d) communities and communities of reflective practice;

e) Data driven reflection, decision-making and continuous improvement, drawing on self-evaluation and feedback to inform next steps in learning and teaching” (UNESCO, 2020, p. 17).

Situation in a modern world requires organize learning not only in the classrooms but also using different e-learning tools.

The paper aims to explore theoretically grounded and practically piloted etools relevant for personalization and currently used in different teacher education practices. The paper presents several e-tools: digital storytelling, three step interview and e-portfolio. This study is based on the scientific literature review and the presentation of several cases.

\section{E-tools for Personalized Learning}

PL requires the adaption of the teaching/learning methods, curriculum and learning environment. "ICT use and E-Learning classrooms are a key element to creating a PL environment” (Williams, 2013, p.10). Student must be active and participate in learning process from the beginning. Williams (2013) has identified six critical areas to ensure PL: (1) locus of control; (2) knowing students as learners; (3) student engagement; (4) collaboration; (5) effective use of ICT; (6) classroom culture. 
Students in schools are active in cyberspace and they usually do not have difficulties to using different e-tools. The task of teacher is to ensure effective use of these methods and tools. The paper presents possibilities of effective use of digital storytelling, three step interview, e-portfolio for PL.

\section{Digital Storytelling}

Storytelling is not a new method and has been widely used in different educational contexts. Storytelling might be defined as the interactive process of using words and actions to reveal the elements and images of a story while encouraging the listener's imagination. Storytelling is increasingly recognized as having important theoretical and practical implications (Kim, 1999). The method of storytelling is useful for young children to develop their vocabulary, concentration, comprehension, ability to think symbolically and metaphorically, to enhance fluency. In a research study by Walker (2001), stories were presented to children in three ways: telling, reading, and CD-ROM. Children in the storytelling group attained higher scores in comprehension than children in the other groups. Storytelling is also useful for enhancing attention-giving and for social capacities. Stories engage thinking, emotions, and can even lead to the creation of mental imagery (Green \& Brock, 2000). As stated Polichak and Gerrig, "individuals listening to stories react to them almost automatically, participating, in a sense, in the action of the narrative” (Polichak \& Gerrig, 2002, p.88). According to Green (2004) shared narrative can be a force in creating community. Digitalization affected educational processes and storytelling has become more widely practiced pedagogical approach in teaching and learning (Miller, 2009). Technologies enable to use not only oral or written stories, but they become digital stories and are accessible for anyone and anywhere in the world. Digital Storytelling can provide todays' learners with strong foundations in the most demanded skills for $21^{\text {st }}$ century, which are connected with ICT literacy, ability to conduct online searches, use different online tools and multimedia to tell a story (Mellon, 1999).

Digital storytelling was first developed at the Center for Digital Storytelling in California in the late 1980s. "Digital Storytelling is the modern expression of the ancient art of storytelling” (Barrett, 2006). This gives possibility to ensure student-centered learning strategies based on their engagement, reflection, project-based learning, and the effective integration of technology into instruction (McDrury \& Alterio, 2000). Figure 1 presents links between digital storytelling and other learning strategies: student engagement, project-based learning, technology integration and reflection for deep learning which are also important for PL. 


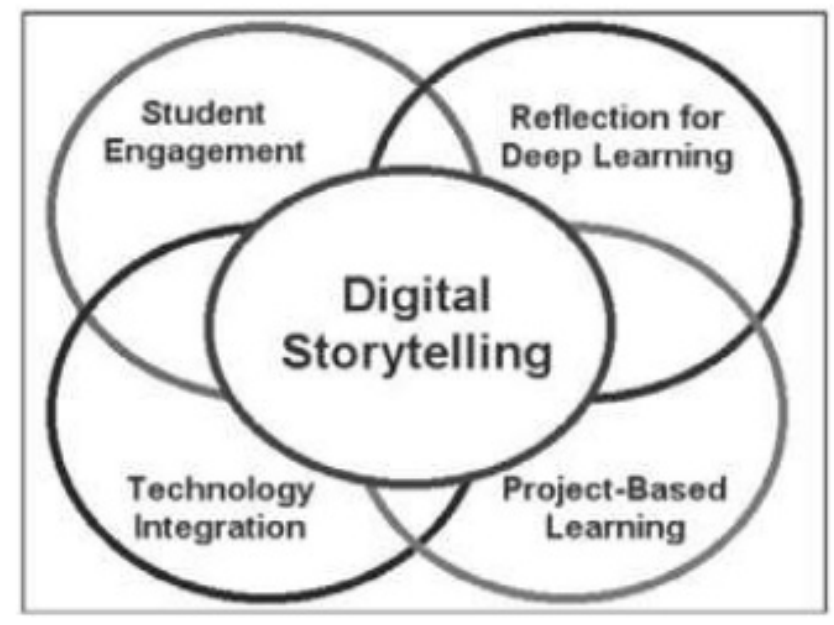

Figure1 Convergence of Student-centered Learning Strategies (Barret, 2006)

By encouraging students to organize their own ideas into individual stories, digital storytelling can easily support learning in different disciplines. Some of the advantages of integrating digital storytelling in classroom have been identified by Gils (2005): (1) Digital storytelling can provide more variations of learning than traditional methods; (2) It can personalize learning experience; (3) Can make the explanation of certain topics less complex; (4) Can create real life or problemsolving situations; (5) Can improve learners' engagement in learning process.

Barret (2006) states that digital storytelling enhances student learning, motivation, engagement, builds technology skills, and it is more effective than paper-based reflection. "Digital storytelling combines the art of telling stories with a variety of digital multimedia, such as images, audio, and video. Just about all digital stories bring together some mixture of digital graphics, text, recorded audio narration, video and music to present information on a specific topic." (Robin, 2008).

Digital storytelling encourages additional educational outcomes by enhancing motivation and creativity, increasing collaboration and peer-to-peer teaching (Kreps, 1998). "Digital storytelling allows computer users to become creative storytellers through the traditional processes of selecting a topic, conducting some research, writing a script, and developing an interesting story" (Robin, 2006, p. 222) - these elements are extremely important for PL.

\section{Three Steps Interview}

A Three Steps Interview is a form of participatory interview approach, developed by the International Women's Group, Eugene, Oregon (Bodone, Dalmau, Doucouré, Guðjónsdóttir, Guðjónsdóttir, Ishak, et al., 1997; 
Dalmau \& Guðjónsdóttir, 2017). It was designed to support participative, equitable and reflective approaches to life history research interviews in small groups of three-five participants. "In this interview format, all participants take turns in three rotating roles (as interviewer, interviewee, and reflective notetaker). If there are more than three people in the group, the group asks two people to share the note taker or facilitator roles. It is imperative that each group member handles a role. The following describes each role:

1. Interviewer: facilitates the discussion and asks the questions.

2. Interviewee: shares her practice and experience with the group.

3. Reflective Note-taker: takes notes and at the end of the session gives brief feedback on the process of the interview, including what impressed him/her in the discussion" (UNESCO, 2020, p.28).

As it is presented in the UNESCO document "Personalized Learning within Teacher Education A Framework and Guidelines" the Three Step Interview "to be effective, several steps are suggested to follow:

1. Participants are paired or in a group of three. One participant interviews the other on a given topic. One participant takes notes or records the interview.

2. Participants rotate roles and repeat step 1.

3. Pairs or trios join another pair or a trio. Then, in a Round Robin format, they share what they have learned from their interviews.

4. Variation: Report to the whole group.

5. Agree on an amount of time for each person to share before the interview begins" (UNESCO, 2020, p.28).

The same document states that "it is important to: (1) Model good listening and interviewing skills, such as eye contact and active listening. Participants should remember that this is an interview not a conversation. (2) Model good open-ended questions, such as How did you...? Tell me about... (3) Model good follow up questions, such as: Tell me more..., Explain...

With advances in technology, most participants now use their phones to record the interview and then they can listen to themselves repeatedly, which helps in thinking about their practice and writing it up" (UNESCO, 2020, p.28).

To understand the various occasions and ways to use this approach we offer three different cases, the first one is from teacher educators' project, and the next two from teacher education classes.

\section{Multicultural Teacher Education}

At the University of Iceland 14 teacher educators participated in a cooperative self-study project for two years. The study aimed to develop a dialogic space that would mobilize teachers' diverse experiences and perspectives to build a framework for multicultural teacher education (Gísladóttir \& Óskarsdóttir, 2019). One of the tools they used was the participatory interview 
approach. The educators worked in groups of two or three. The goal with the interviews was to aid their understandings of how their cultural backgrounds influence their work as teacher educators.

The interviewers asked the interviewees: to explain their understanding of multicultural education; tell about how they came involved in/where their interest in multicultural education came from; and explain their instructional methods, how they make learning spaces for all and create classroom climate that welcomes everyone's participation.

During the interviews the participants experienced that even though their background was diverse what they had in common was an experience of being an outsider in a community at some time in their life. Their vision for multicultural education was built on their experience and welcoming all learners in their learning communities was at their heart. The participatory interview helped them make a dialogic space that allowed them to problematize and rethink teacher education collectively.

\section{Working Inclusive Practices}

One of the main topics of the course Working in Inclusive Practices (WIP) at the University of Iceland is professional working theory (PWT) (Dalmau \& Guðjónsdóttir, 2017). Early in the autumn semester of 2020, teacher students who were enrolled in the course were asked to explore, reflect on, and relate their practice (experience of their work/roles) to theory (theoretical framework and their explanations for what happens in the classroom) and ethics (reasons behind their practice, their beliefs, and values about the world).

Students were assigned randomly into groups of three and took a 12 minutes' turn in each role, in line with the participatory interview approach. They were provided with interview questions, including: "What made me proud in my practice last time? What policies or legislation did I follow? What societal issues do I see in my school and how do I see these reflected in my practice?” After the interviews, each student received reflective notes and started to develop his/her professional working theory. One of the teacher students commented on the task: "It was interesting to practise taking interviews, listen and write down about others who are complete strangers. I got ideas from them and it is a brilliant way to hear from others about things you yourself might not have considered. I managed to think about my professional working theory and how I want to shape my practice when I start to teach.”

\section{Action research course}

Action research is a selective course for graduate students. Students choose their topic for their project and through the years we have learnt that our students often find it hard to set their focus. As a student reported: "How do I choose a topic? Can I do whatever I would l like to do?" Another one asked: "What kind of methods can we use?” Therefore, we decided to see if the three-step interview 
approach could support them in finding their topic, setting the purpose, deciding the aim and developing the research question.

The students were assigned randomly to groups of three, the process was introduced and what to pay attention to. The basic questions were: "Tell us about your idea for the research, why do you want to research this topic and what would you like to see at the end of the action research.” The interviews were recorded for students to use as they drafted their research proposal. Students reported that the activity was helpful as they began to write their proposal. "During the interview I began to develop an idea for my action research" a student wrote in her personal evaluation and another one said: "The interview was helpful for me to frame my idea."

We have noticed that for diverse group of students who are either current or prospective teachers, the participatory interview approach emphasizes equity by offering insights into complexity of everyone's experiences and practice and acknowledging value and learning from all of them. We have learnt that experienced teachers are both excited and thankful for this activity because they have a story to tell but do not often get an opportunity to tell it. Our experience suggests that moving from discussions to interview mode is often a challenge. Sometimes it seems to be difficult for the interviewers to just listen and to keep their own stories to themselves. They have to be reminded all the time of their role and its importance. The note-takers are similarly important because they not only take the notes but also keep time, pose questions that have not been asked or ask for clarification. By following the steps provided in this section and responding to the challenges that may arise, the participatory interview approach can be useful for teacher educators and teacher students because it opens a space for all to get to know each other and oneself and to reflect on their current practice or ideas for the future ones.

\section{E-portfolio as an Instrument and Environment for Personalized Learning}

E-portfolio is widely used in higher education seeking to help learners collect evidence about their learning, to consider assessment, develop critical thinking and prepare for lifelong learning (Bolliger, Shepherd, 2010; Mahasneh, Omar, 2020). The investigation by Colás-Bravo, Magnoler, Conde-Jiménez (2018) has proven that e-portfolio is like a kind of a tool and a source having a large potential to develop harmonious awareness of university students. Students become more engaged in the creation of the process of learning, and this increases their awareness and abilities (Gámiz-Sánchez, Gallego-Arrufat, \& Crisol-Moya, 2016). According to Alajmi (2019), the usage of e-portfolio improves learners' abilities, skills and knowledge, reveals strengths and weaknesses. 
Each learner is unique, having one's own learning style, pace, whereas knowledge and abilities differ because of cultural differences (Sfenrianto, Hasibuan, Suhartanto, 2011). Unfortunately, traditional teaching and learning cannot recognize these differences (Laksitowening, Hasibuan, 2015). As the authors have it, e-learning provides conditions for PL, while meeting learner's needs, co-creating the scenario for learning. E-portfolio is one of the instruments which provide conditions for the manifestation of PL. In scientific research, application of e-portfolio in the process of learning is dealt with as a learning instrument, a learning environment (Barrett, Carney, 2005), a learning strategy (Bolliger, Shepherd, 2010), a means for career development and employment (Ciesielkiewicz, 2019), an assessment instrument (Barrett \& Garrett, 2009) or/and a means of feedback for both students and university teachers (Vázquez-Cano, López Meneses \& Jaén Martínez, 2017; Händel, Wimmer \& Ziegler, 2018). PL is concerned about creating conditions for a learner to take responsibility for one's own learning (Jaros, Deakin-Crick, 2007). Application of e-portfolio ensures authentic learning because learners organize the filling-in of their e-portfolio, contemplate on their learning processes, draw conclusions, improve learning with regard to their considerations (Goldsmith, 2007; Reese, Levy, 2009), it helps learners to set personal goals related to their learning.

PL is being personally monitored, dynamic (Karmeshu, Nedungadi, 2012), whereas the practice of application of the e-portfolio provides conditions to evaluate the processes of own learning and implement required corrections based on own reflections (Goldsmith, 2007; A. Yastibas, G. Yastibas, 2015). These are the conditions for authentic assessment and evaluation (Sewell, Marczak, Horn, 2005):

- $\quad$ provides conditions for a university teacher to see a student, group or a community as individual, unique, having one's own features, needs and strengths;

- $\quad$ serves as a cross-section lens providing a fundamental for future analysis and planning;

- $\quad$ serves as a particular communication means ensuring continuous communication and information exchange among participants;

- $\quad$ provides a possibility to remove drawbacks of traditional assessment and evaluation; provides a possibility to assess more complex and important aspects of a particular area or theme;

- $\quad$ covers a broad spectrum of knowledge and information from many interested individuals who have knowledge, e.g. a programme or a person in different situations (e.g. mentors, tutors, peer or community leaders). 
Interactivity is important for PL (Nedungadi, Raman 2012), and the fillingin of e-portfolio is inseparable from communication with a university teacher, friends to improve learning (Bolliger, Shepherd, 2010; Lin, 2008). Seeking to improve learning, feedback is highly important. E-portfolio provides conditions for not only a learner, but also for a university teacher to get it to correct the goals, assessment criteria, methods, teaching and self-assessment approaches as well as content (Goldsmith, 2007).

Application of e-portfolio as a PL instrument, an environment, focuses on the following university teacher's skills: facilitation, active listening, provision of feedback, intervention, assessment (Attwell, 2009). Suggested holistic approaches to adapting e-portfolio in practice would cover the institutional level, the curriculum, the process of learning, the personal and e-portfolio levels (Beckers, Dolmans, van Merriënboer, 2016).

\section{Conclusions}

These tools and presented activities are examples of PL as they enable participants to link to individual experience, aspirations and motivation through collaboration and involvement in the learning process. They can be used with diverse groups of learners, including student teachers and teacher educators. Each of presented tools includes more than one out of six identified areas to ensure PL. Digitalization led to transformations from traditional to modern application of well-known tools. This is one of identified areas to ensure PL. All three tools ensure student engagement, students become more motivated and they might manage their time.

\section{Acknowledgements}

The research has been funded by Erasmus+ project "Innovative Teacher Education through Personalized Learning“ (2018-1-LT01-KA203-046979). This publication reflects the views only of the author, and the Commission cannot be held responsible for any use which may be made of the information contained therein.

\section{References}

Alajmi, M. M. (2019). The impact of e-portfolio use on the development of professional standards and life skills of students: a case study. Entrepreneurship and sustainability issues, 6(4) (June), 1714-1735. DOI: https://doi.org/10.9770/jesi.2019.6.4(12)

Alisauskiene, S., Guðjónsdóttir, H., Kristinsdóttir, J. V., Connolly, T., O'Mahony, C., Lee, L., Milteniene, L., Meliene, R., Kaminskiene, L., Rutkiene, A., Venslovaite, V., Kontrimiene, S., Kazlauskiene, A., \& Wozniczka, A. K. (2020). Personalizedlearning 
Rutkiene et al., 2021. Tools for Personalized Learning-based Teacher Education

within teacher education: A framework and guidelines. UNESCO. https://unesdoc.unesco.org/ark:/48223/pf0000374043?fbclid=IwAR0H9a6pvp340bGLB VeB_h8kDUnX65ij7lZ0K8MeU7IQnk5RsD3v2P6jP_I

Attwell, G. (2009). e-Portfolios - the DNA of the Personal Learning Environment. Journal of E-Learning and Knowledge Society, 3(2), Italian e-Learning Association. Retrieved from https://www.learntechlib.org/p/43421/

Barrett, H. (2006).Researching and evaluating digital storytelling as a deep learning tool. In Society for Information Technology\&Teacher Education International Conference, Vol. 2006, No. 1, 647-654, Chesapeake, Virginia, AACE.

Barrett, H. \& Carney, J. (2005). Conflicting Paradigms and Competing Purposes in Electronic Portfolio Development.

Barrett, H. C., \& Garrett, N. (2009). Online personal learning environments: structuring electronic portfolios for lifelong and life-wide learning. On the Horizon, 17(2), 142-152.

Beckers, J., Dolmans, D., \& van Merriënboer, J. (2016). E-Portfolios enhancing students' selfdirected learning: A systematic review of influencing factors. Australasian Journal of Educational Technology, 32(2). DOI: https://doi.org/10.14742/ajet.2528

Bodone, F., Dalmau, M. C., Doucouré, K., Guðjónsdóttir, H., Guðjónsdóttir, V., Ishak, N., et al. (1997, March 24-28). Inside looking in:Participatory life history research in education. [Paper presentation]. Talking Together in Educational Research and Practice American.Educational Research Association, Chicago.

Bolliger, D. U., \& Shepherd, C. E. (2010). Student perceptions of ePortfolio integration in online courses. Distance Education, 31(3), 295-314. DOI: https://doi.org/10.1080/ 01587919.2010.513955

Ciesielkiewicz, M. (2019). The use of e-portfolios in higher education: From the students' perspective, Issues in Educational Research, 29(3), 649-667.

Colás-Bravo, P., Magnoler, P., \& Conde-Jiménez, J. (2018). Identification of Levels of Sustainable Consciousness of Teachers in Training through an E-Portfolio. Sustainability, 10(10), 1-18. DOI: 10.3390/su10103700

Dalmau, M. C., \& Guðjónsdóttir, H. (2017). From the beginning to the future: Professional working theory emerging. In M. C. Dalmau, H. Guðjónsdóttir \& D. Tidwell (Eds.), Taking a fresh look at education:Framing professional learning in education through self-study (pp. 129-148). Sense Publishers.

Gámiz-Sánchez, V. M., Gallego-Arrufat, M. J., \& Crisol-Moya, E. (2016). Impact of electronic portfolios on prospective teachers' participation, motivation, and autonomous learning. Journal of Information Technology Education: Research, 15, 517-533. DOI: https://doi.org/10.28945/3575

Gils, F.V. (2005). Potential Applications of Digital Storytelling in Education. Netherlands: University of Twente. Retrieved from: https://www.semanticscholar.org/paper/PotentialApplications-of-Digital-Storytelling-inGils/2667b549f648de5d20cc8ed8d6bb1eafb0577c9b?tab=references

Gísladóttir, K. R. \& Óskarsdóttir, G. (2020). Envisioning new ways of knowing: Toward a shared vision of multicultural teacher education through collective self-study. In C. Edge, A. Cameron-Standerford, \& B. Bergh (Eds.), Textiles \& tapestries: Self-study for envisioning new ways of knowing. EdTech Books. https://edtechbooks.org/textiles_ tapestries_self_study/chapter_104

Goldsmith, D. J. (2007). Enhancing learning and assessment through e-portfolios: A collaborative effort in Connecticut. New Directions for Student Services, 119, 31-42. DOI: $10.1002 / s s .247$ 
Green, M. C. (2004). Storytelling in teaching. Observer, 17(4), 37-38, 52-54. Retrieved from www.psychologicalscience.org/observer/getArticle.cfm?id=1562

Green, M. C., \& Brock, T. C. (2000). The role of transportation in the persuasiveness of publicnarratives. Journal of Personality and Social Psychology, 79, 401-421.

Guðjónsdóttir, H. (2000). Responsive professional practice: Teachers analyse the theoretical and ethical dimensions of their work in diverse classrooms. Unpublished dissertation. Eugene: University of Oregon.

Händel, M., Wimmer, B., \& Ziegler, A. (2018). E-portfolio use and its effects on exam performance - a field study. Studies in Higher Education, 45(2), 258-270. DOI: https://doi.org/10.1080/03075079.2018.1510388

Jaros, M., \& Deakin-Crick, R. (2007). Personalized learning for the post-mechanical age. Curriculum Studies, 39(4), 423-440. DOI: https://doi.org/10.1080/00220270600988136

Karmeshu, Raman, R. \& Nedungadi, P. (2012).Modelling diffusion of a personalized learning framework. Educational Technology Research and Development, 60, 585-600. DOI: https://doi.org/10.1007/s11423-012-9249-2

Kim, S.Y. (1999). The effects of storytelling and pretend play on cognitive processes, shortterm and long-term narrative recall. Child Study Journal, 29(3), 175-191. Kreps, G. L. (1998). The powers of story to personalize, enrich, and humanize communication education. Paper presented at the Annual Meeting of the National Communication Association, New York, NY.

Laksitowening, K. A., \& Hasibuan, Z. A. (2015). Personalized E-Learning Architecture in Standard-Based Education. 2015 International Conference on Science in Information Technology (ICSITech), 110-114. DOI: https://doi.org/10.1109/ICSITECH.2015. 7407787

Lin, Q. (2008). Preservice teachers' learning experiences of constructing e-portfolios online. Internet and Higher Education, 11(3), 194-200. DOI:10.1016/j.iheduc.2008.07.002

Mahasneh, O. M. K. (2020). A Proposed Model for the University Students' E-Portfolio. Journal of Education and e-Learning Research, 7(1), 28-33. DOI:10.20448/ journal.509.2020.71.28.33

McDrury, J., and Alterio, M. (2000). Achieving reflective learning using storytelling pathways. Innovations in Education and Teaching International, 38(1), 63-73.

Mellon, C.A. (1999). Digital Storytelling: Effective learning through the Internet. Education Technology, 39(2), 46-50.

Miller, W. R., Rose, G. S. (2009). Toward a theory of motivational interviewing. American Psychologist, 64(6), 527-537.

Nedungadi, P., \& Raman, R. (2012). A new approach to personalization: integrating e-learning and m-learning. Educational Technology Research and Development, 60, 659-678. DOI: http://dx.doi.org/10.1007/s11423-012-9250-9

Polichak, J.W., \& Gerrig, R.J. (2002). Get up and win: Participatory responses to narrative. InGreen, M. C., Strange, J. J. \& Brock, T. C. (Eds.), Narrative impact: Social and cognitive foundations, (pp. 71-96). Mahwah, NJ: Erlbaum.

Reese, M., \& Levy, R. (2009). Assessing the future: E-portfolio trends, uses, and options in higher education. ECAR Research Bulletin, 2009(4), 1-12.

Robin, B. R. (2008). Digital storytelling: A powerful technology tool for the 21st century classroom. Theory into practice, 47(3), 220-228.

Sewell, M., Marczak, M., \& Horn, M. (n.d.). The use of portfolio in assessment in evaluation. URL: http://ag.arizona.edu/fcs/cyfernet/cyfar/Portfo 3.htm 
Sfenrianto, S., Hasibuan, Z. A., \& Suhartanto, H. (2011). The Influence Factors of Inherent Structur in E- Learning Process. International Journal of e-Education, $e$-Business, $e$ Management and e-Learning, 1(3), 217-222. DOI:10.7763/IJEEEE.2011.V1.34

Vázquez-Cano, E., López Meneses, E., \& Jaén Martínez, A. (2017). The Group e-portfolio to improve Teaching-Learning Process at University. Journal of e-Learning and Knowledge Society, 13(2), 65-76. DOI: https://doi.org/10.20368/1971-8829/1221

Walker, V.L. (2001). Traditional versus new media: storytelling as pedagogy for AfricanAmerican children (Doctoral dissertation, The University of Texas at Austin, 2001). Dissertation Abstracts International, 62, 820.

Williams, S. (2013). Practical ways that schools can personalise learning for their students Powerful learner pit stops. In Principal sabbatical report 2013. Retrieved from: http://www.educationalleaders.govt.nz

Yastibas, A., E. \& Yastibas, G., C. (2015). The use of e-portfolio-based assessment to develop students' selfregulated learning in English language teaching. Social and Behavioral Sciences, 176, 3-13. DOI: https://doi.org/10.1016/j.sbspro.2015.01.437

Zmuda, A. Curtis, G. \& Ullman, D. (2015). Learning Personalized: The evolution of the contemporary classroom. San Francisco, CA: Wiley/Jossey. 